\title{
The TurkStream Pipeline in Light of the Security of Demand for Russian Gas
}

\author{
Attila Virag, (PhD) \\ Corvinus University of Budapest, Hungary
}

URL:http://dx.doi.org/10.19044/esj.2018.v14n29p16

\begin{abstract}
The purpose of this paper is to analyse the TurkStream project in light of the security of demand for Russian natural gas. The analysis focuses on the relations between the EU and Russia, with further focus on Eastern Europe, accompanied by a description of the power engineering actions affecting the old continent from 2014 to date. Based on the analysis, it can be established that although on the face of it, the Russian-inspired project has policy and business goals, but demand security considerations also lie in the background, fuelled by significant geopolitical endeavours.
\end{abstract}

Keywords: Russia, TurkStream, energy security, security of demand, gas projects, pipelines

\section{Introduction}

In the 21st century, Russia's power lies primarily in its outstanding hydrocarbon base rather than its economic or military capacity. Regarding the natural gas sector, Russia's potential can be grasped from either the supply or the demand side. According to the statistics compiled by BP, the continentsized country has the highest volume of recoverable reserves in the world, amounting to 35,000 billion cubic meters or 18.1 per cent of the total natural gas reserves on the Earth. More than 635.6 billion cubic meters of this amount were being extracted at the end of 2017 , representing more than 17.3 per cent of the global production. Of this amount, 215.4 billion cubic meters were intended to be transported through pipelines per annum, which ranks the country first in the world in respect of export volumes (BP, 2018). Europe is the traditional market for Russian natural gas. In 2017, nearly 88 per cent of the Russian piped natural gas intended for export was sold on the old continent, and this amount provided more than 35 per cent of Europe's total gas consumption (531.7 billion cubic meters per annum, (BP, 2018). In a breakdown by country, it is clear that the dependence of the European Union's eastern Member States on Moscow for natural gas is considered as especially 
high: Latvia, Slovakia, Finland and Estonia purchase 100 per cent, the Czech Republic, Bulgaria and Lithuania 80 per cent, Greece, Austria and Hungary 60 per cent of the gas they need from Russia (Marshall, 2016). These peculiar data have led to a peculiar Russian natural gas strategy, including a one-off tactical element called the "TurkStream Gas Pipe Project".

This paper has a double purpose: on the one hand, the considerations that have called forth this large-scale project are described, on the one hand, and intends to evidence that the Russian concept differs to a large extent from the classical policy and project implementation plans, on the other. The reason is that although prima facie the Russian-inspired project is aimed at policy and business goals, demand security considerations fuelled by significant geopolitical endeavours also lie in the background. This analysis focuses on the relations between the EU and Russia, with particular attention to Eastern Europe, and is complete with a description of the power engineering actions affecting the old continent from 2014 to date. In respect of the TurkStream, the Russian demand security strategy of the past few years are studied, excluding the concepts related to the 2014 downslide in oil prices.

\section{Russian energy security and security of demand}

As an indispensable prerequisite to professional approach to this field, the concept of energy security needs to be determined, but unfortunately, there is no uniform international definition. ${ }^{1}$ When experts, primarily from the West, attempt to define energy security, they take the security of and provision for energy supply to a given economic and/or political region as their starting point. In this approach, the aim of energy strategy is to ensure uninterrupted energy supply using various political and economic implements. This strategy is primarily adopted by regions with very limited sources of energy and hydrocarbon reserves or not at all. The energy strategies applied by importers are thus determined by the pressure of long-term import. For this reason, net energy importers are disposed to consider the terms "energy security" and "supply security" as synonyms, despite the fact that the approach focusing on supply is only one version of energy strategy. The uneven geographical distribution of energy sources, primarily hydrocarbons, which took on priority during the Cold War, was accompanied by a diversity of energy strategies. Therefore, in countries which have access to abundant mineral oil and natural gas resources, and as such, are highly likely to be exporters, the above strategy has no explanatory force. In this case, energy security focuses on ensuring the security of demand and on using incomes earned on supply for the achievement of political and/or economic goals. Instead of allocating assets to the goal of

${ }^{1}$ The concept of energy security may be approached in numerous ways, from traditional definitions based on survival (Buzan et al., 1998) to explanations emphasizing two (Cherp et al., 2012) or more dimensions (Wicks, 2009, 8). For more details, see Weiner (2017, 3-5). 
securing energy supply, the income derived from energy supply (energy export) is (or may be) allocated to various political and/or economic goals. Such goals are generally unrelated to the energy industry, and in most cases, they are economic or geopolitical in character. This concept highlights the number one aim of Russian energy policy in the piped natural gas business. As a net energy exporter, Russia's primary aim is to maintain/increase the security of supply in the natural gas sector.

\section{Initial situation}

In order to understand the emergence of the idea of the TurkStream Project, it is indispensable to have a look at its macroeconomic environment. ${ }^{2}$ This paper focuses on one of the potential terminals of the envisaged pipe network, the eastern part of the EU. The concept of the TurkStream was inspired and is affected by numerous events, like Russia's relations with Ukraine, the European Union and the United States. Before a presentation of an alternative pipeline plan, the potential competitors also need to be mentioned, whether they are alternative pipeline plans or countries with potential gas resources.

\section{The Russian-Ukrainian conflict}

Although for a long time Russia might have secretly hoped to be able to stabilize the transit of Russian gas through Ukraine, however, these hopes failed with the events of late 2013, which led to a conflict between Kiev and Moscow, to Russia's annexation of Crimea in 2014, and to armed conflicts in Eastern Ukraine. As Ukraine and Russia are de facto at war, in order to retain its significant economic and political blackmailing potential, the former definitely does not want to give up Ukrainian gas transit. ${ }^{3}$ Moreover, as Kiev wanted to eliminate its dependence on Russian natural gas, they took action to increase their energy independence. Prior to the escalation of the RussianUkrainian conflict, in 2010 approximately 60 billion cubic metres of natural gas was consumed in Ukraine per annum, 66 per cent was imported from Russia and 33 per cent came from domestic extraction. In 2017, consumption fell to nearly half, i.e. 32 billion cubic metres. They have maintained domestic extraction at approximately 20 billion cubic metres, and the remaining part is imported from the European Union through Poland, Slovakia and Hungary. The Russian-Ukrainian relations are further strained by the court cases related to natural gas transit. Back in January 2016, the Ukrainian Anti-Monopoly

\footnotetext{
${ }^{2}$ As in economics stakeholder-oriented leadership (Blaskovics 2016) is a crucial issue, the interests of regional and global stakeholders are also of key importance in energy strategies (Deutsch, 2013).

${ }^{3}$ In the mid-2000s, the overwhelming majority of the Russian natural gas export was delivered to Western Europe through Ukraine. This made Kiev one of the pivotal gas transit stations in the world.
} 
Commission imposed a fine of 85.9 billion hryvna on Gazprom for the unilateral abuse of natural gas transit, and this decision has been approved by several Ukrainian courts since then. This conflict is also taking place in the international arena: in February 2018, the Stockholm Arbitration ordered Gazprom to pay USD 2.56 billion for underperforming its transit contract concluded with the Ukrainian Naftogaz. ${ }^{4}$

\section{Western decisions and sanctions against Russia}

As a result of a change in the legal status of Crimea, relations between the Western world and Russia are not ideal. The parties have adopted mutual sanctions against one another, and extend them every six months. Relations only deteriorated with the poisoning of the late Sergey Scripal, a Russian spy living in England. Due to the sanctions, neither the current state nor the prospects are bright for the Russian economy. ${ }^{5}$ Moscow is only given limited access to Western capital and technology (Tarar et al., 2018). The effects of the sanctions were somewhat mitigated by the central fund established during the time of higher oil prices. However, the reserves saved in this fund were used for offsetting the budget losses suffered on account of the low energy prices instead of restructuring the economy.

The third energy package of the EU, which entered into force in March 2011, hit the Russian security of demand seriously. The provisions of the document effectively prevented the Russian-inspired Southern Steam from reaching the territory of the EU. ${ }^{6}$ In addition, three years ago, the European Commission launched an antitrust investigation against Gazprom based on complaints by five Central and Eastern European countries claiming that the Russians were abusing their competitive advantage and were exporting natural gas at a price significantly above the market rate. Based on the investigation it was established that the Russian company had infringed upon the European Union's antitrust rules by adopting a comprehensive strategy for the distribution of the natural gas market between eight Member States of the EU, namely Bulgaria, the Czech Republic, Estonia, Hungary, Poland, Latvia, Lithuania and Slovakia, and this enabled the company to charge higher gas

\footnotetext{
${ }^{4}$ In June 2018, the appellate court of Svea County in Sweden suspended the enforcement of the decision adopted by the Stockholm Arbitration. Then Naftogaz sought actin in Switzerland, Great Britain and the Netherlands in order to seize and obtain certain European assets and shares of Gazprom.

${ }^{5}$ The situation of the Russians was further aggravated by the fact that oil prices dropped and got stuck at a low level.

${ }^{6}$ The conceptual scheme of the Southern Stream was devised to maintain the gas supply status quo in Central and Eastern Europe. The project promised an alternative natural gas corridor interlinking Europe with Russia, as a means to put political pressure on Ukraine. The pipe plan was a promise for the countries rich in natural gas in the Caspian Region for the maintenance of export to the West through Russia. For further details see Virág, 2014.
} 
prices in five countries: Bulgaria, Estonia, Latvia, Lithuania and Poland. The European Commission set requirements for the natural gas supplier Gazprom, and these significantly changed the service provider's operation in the Central and Eastern European gas markets.

In addition to the EU, the USA also imposed sanctions on Russia. The American legislation launched the first wave after the occupation of Crimea, and the second one in response to Russia's presumed interference with the US election campaign. In 2017, the American Congress approved the sanction package, among others already with the key objective of paralyzing the Russian natural gas industrial project, including the construction of new pipelines (CAATSA, 2017). Although Washington refuted that these sanctions served as means of enforcing US corporate and economic interests, the statutes clearly specified the natural gas pipe project called Nord Stream 2 (see below).

\section{Alternative network projects in Eastern Europe}

As in the eastern part of the EU the natural gas supply network was made for the westward export of Soviet gas, in Eastern Europe a pipe network was made in an east-west direction. For this reason, networks in the north-south direction were missing in the region for a long time. The Russian-Ukrainian conflicts (especially the 2006 and the 2009 gas crises) clearly showed that in the eastern part of EU, the natural gas supply network required significant improvements. For this very reason, numerous countries in the region saw significant opportunities in the creation and improvement of so-called crossborder capacities interlinking Member States for the purposes of natural gas supply. In addition, there is great potential in exploring alternative transport and extraction technologies, including the unfolding of LNG import and unconventional gas extraction. In the eastern part of the EU, it is worth emphasizing the concept of the north-south energy corridor (New Europe Transmission System, NETS). The novelty of the policy is that it provides an opportunity for direct natural gas trade in a north-south direction within the European Union, exclusively with east-west links.

In the framework of the concept, numerous new interconnectors were implemented in the past decade and may be established in the future. The European Commission also provides significant support for these projects. Thus, most recently, in February 2017, EUR 444 million has been approved for 18 European electricity and natural gas infrastructure projects to the debit of the CEF fund promoting the interconnection of Member States. In the framework of the north-south energy corridor, funds are provided in the amount of EUR 4 billion for natural gas pipes (European Commission, 2017). 
The highest amount, EUR 108 million, is granted for the construction of the Polish-Slovakian interconnector pipeline. ${ }^{7}$

At Krk Island in Croatia, a facility suitable for receiving liquefied natural gas would be established. According to the plans, the terminal would be initially suitable for receiving 2.6 billion cubic metres of natural gas. If implemented, these capacities may be expanded in the future. The geopolitical significance of the capital investment project exceeds its economic importance, as it may provide an alternative to the import of Russian natural gas for the countries of the region, and can at the same time lower the purchase price of the latter. This capital investment project is also supported by the EU (List, 2017).

As a northern counterpart of the Croatian LNG terminal, in October 2015, the liquid natural gas terminal of a similarly strategic significance was handed over in Swinoujscie, in the north of Poland, to diversify gas supply. The company Polskie LNG is in the ownership of the Polish state-owned GazSystem. The terminal that has two gas containers has a capacity of 5 billion cubic metres. The pipelines built from the Baltic Seas gas port may transmit natural gas towards Gdansk and Lwówek. Thus, with the help of the existing gas interconnections, natural gas may well be supplied to other countries in the region. The terminal may contribute to releasing Poland from its need to import natural gas from Russia by 2022, after the expiry of the long-term contract concluded with Gazprom.

\section{Alternative resource countries in Eastern Europe}

The potential inherent in unconventional natural gas resources and the related technology resulted in a major breakthrough in the United States. The development also coined as the "American shale gas revolution" enabled extraction from natural gas fields that had previously been known but were difficult and very costly to access. Thus by the 2010s, the USA had become the largest gas extractor in the world.

The LNG technology opened up a way for the American natural gas to Europe. Since early 2016, the old continent's import of American LNG has increased from zero to 2.8 billion cubic metres per annum, which also means that the share of LNG export from the US to Europe grew from 3 to 10 per cent between 2016 and 2017. Although the current volume is insignificant, the American efforts reveal that the objective of the US policy is to create a market for the American liquefied natural gas in Europe, and to discourage Russia's dominance in the regional gas market. ${ }^{8}$ Complete with the EU's support to the

\footnotetext{
${ }^{7}$ The European Investment Bank provides a EUR 70 million loan for the implementation of the gas pipeline, which may have been completed by 2021 according to the plans.

${ }^{8}$ In addition to the LNG export terminal located in Louisiana, USA, five other harbours may be built in the next 2 to 3 years.
} 
LNG technology, ${ }^{9}$ this already poses a serious risk to the security of demand for Russian natural gas.

The above described terminal already operative in Poland, and the one waiting for implementation in Croatia are key factors in the European energy game: through these terminals, in the future, Eastern-European countries may purchase American natural gas in bulk. ${ }^{10}$ Although in the price competition, the LNG received from the USA is in a less favourable position than the Russian natural gas, this may be partly offset by the above-specified American sanctions.

In addition to the USA, Romania also appeared as an exporter on the map of Eastern Europe. In February 2012, the Romanian Petrom, a member of the American ExxonMobil and the Austrian OMV Group, announced that they had found significant natural gas reserves at a deposit called Neptun, located in a depth of 930 metres under the ground and $170 \mathrm{~km}$ from the Romanian shores of the Black Sea. According to the first estimates, the reserves explored at Well Domino 1 may be in the range of 42-48 billion cubic metres. ExxonMobil and OMV Petrom is expected to start the extraction of natural gas from the Black Sea in 2020 or 2021, and 6 billion cubic metres of natural gas is planned to be brought to the surface annually. Thus, the opportunity may open up for the construction of a Romanian-Hungarian-Austrian natural gas corridor. If the project called BRUA is implemented, initially 1.75 billion and after 2022, at least 4.4 billion cubic meters of natural gas may be transmitted through the network from the area of the Black Sea and the Caspian Sea per annum. To this end, the supply capacities of the high-pressure gas network need to be expanded from Romania towards Austria, and new pipelines will also be needed. The EU and the European Bank For Reconstruction and Development also support their implementation. ${ }^{11}$

Finally, it is important to mention another potential source country, Azerbaijan. The natural gas extracted from the Azeri Shah Deniz II field may reach Europe through the Trans Anatolian gas pipeline (TANAP) and the

9 The EU co-financed infrastructure improvement projects related to LNG, or assumed liabilities for financing them, in the amount of EUR 638 million. Thus by 2021, the current capacity of 150 billion cubic metres may increase by an additional 15 billion cubic metres. During the July 2018 meeting of Jean-Claude Juncker and Donald Trump, increase in Europe's import of American LNG was promised.

${ }^{10}$ In January 2018, at a press conference held jointly with his Polish counterpart, former US Foreign Secretary Rex Tillerson mentioned in Warsaw that the Russian natural gas could be replaced by US liquefied natural gas free of risks. In July 2017, Donald Trump also had talks in the Polish capital with Central and Eastern European leaders about American LNG export. ${ }^{11}$ The EUR 149 million contributed by Transgaz, the company in charge of the management of the Romanian natural gas pipe network, was completed by loans granted in October 2017 by the EBRD in the amount of EUR 60 million and EUR 50 million by the European Investment Bank. The total cost of constructing the $1318 \mathrm{~km}$ long BRUA pipeline is estimated at EUR 550 million, of which the EU provides EUR 179 million. 
Trans Adriatic Pipeline $(T A P) .{ }^{12} \mathrm{~A}$ memorandum of understanding to implement the former was signed by the Azeri SOCAR and the Turkish BOTAS and TPAO companies in December 2011, followed by an intergovernmental agreement about the establishment of the gas pipe, signed by Ankara and Baku in 2012. The first pipe was laid in March 2015 in the eastern Kars Province of Turkey. The pipeline would link Azerbaijan's natural gas fields around the Caspian Sea with Europe. The network will run along a total of $1850 \mathrm{~km}$ from the Georgia border to Greece through Turkey, with a $19-\mathrm{km}$ section under the Sea of Marmara. ${ }^{13}$ The total value of the project is approximately USD 8.5 billion.

Through the Trans Anatolian Pipeline, Turkey will receive 2 billion cubic metres of natural gas in the first year, to be increased by 2 billion cubic metres every year to follow, in sum, achieving 6 billion cubic metres per annum by 2021. The remaining 10 billion cubic metres can be sold in Europe. According to the plans, in mid-2019 the pipeline with a total capacity of annual 16 billion cubic metres may be able to transmit natural gas to the Greek border. In the future, network capacity may be increased in two steps: first up to 22 billion per annum, and then up to 31 billion per annum. The pipe network will have two off-take stations in Turkey: one in Eskesehir and another in Eastern Thrace. TANAP will connect to the Trans Adriatic Pipeline (TAP) running towards the west at the Turkish border town Ipsala.

The memorandum of understanding on the TAP pipeline was signed by the representatives of Albania, Italy and Greece at the end of September 2012. The project will cost approximately USD 45 billion, and will be in the ownership of Socar (20 per cent), BP (20 per cent), Snam (20 per cent), Fluxys (19 per cent), Enagas (16 per cent) and Axpo (5 per cent). The Trans Adriatic Pipeline (TAP) would start from Thessaloniki in Greece and reach Southern Italy by the shortest route, passing through Albania and touching the Adriatic Sea. The pipeline is expected to have a capacity of 10 billion cubic metres per annum, with the option to double at a later stage.

\section{General objectives of Russia and its strategic steps}

Having faced the challenges outlined above, Russia wished to stabilize its power positions in the European natural gas sector. The underlying reasons were included both political and economic considerations. Moscow made efforts at achieving the following objectives in the natural gas sector:

- The pacification or unhooking of the gatekeeper countries: ensuring undisturbed and uninterrupted natural gas trade between Russia and the European Union through reconciliation with the transit states, called

\footnotetext{
${ }^{12}$ TANAP is linked to the Shah Deniz II field by the South Caucasus Pipeline (SCP).

${ }^{13}$ Eighty per cent of the pipes used for the construction of the section in Turkey were manufactured by Turkish, and the remaining 20 per cent by Chinese companies.
} 
"gatekeepers", which divide the region, and if this proves impossible, bypassing them using alternative pipe networks.

- To regain the confidence of European consumers,

- To block potential countries of resource: to prevent natural gas extracting and/or exporter countries from direct access, i.e. access without Russian control, to the European markets.

The Russian objectives are based on a strategy of following three pillars:

- Seizing/increasing/retaining control over the transit infrastructure through political influence or pressure, and/or the creation of an alternative transmission infrastructure in order to eliminate the "gatekeepers";

- Guaranteeing safe natural gas supply for European consumers through initiatives made at alternative natural gas projects serving Russian interests;

- To obtain/retain monopoly as a natural gas buyer of alternative sources, and laying the foundations of bids that are more favourable than the alternative sources.

Finally, the compilation of a strategy was started through a complex series of tactical steps, namely by the diversification of the existing Russian transmission routes, or at least its communication in order to exert pressure. One of the manifestations of this series of tactical steps was the TurkStream natural gas pipeline project.

\section{The TurkStream in the service of the Russian natural gas strategy}

The TurkStream project was placed on the agenda as a Russian concept, directly after the Southern Stream had been closed in $2014 .{ }^{14}$ Similarly to the previous pipeline plans, the conceptual scheme of this project serves the retention of Russia's status quo in natural gas supply to Eastern and Central as well as Southern and Eastern Europe. Thus it also applies to the TurkStream that instead of implementation, in the case of gas transmission to the West, the first and foremost project indicator is whether the existing power positions can be maintained and increased or not.

The Russian-inspired alternative natural gas corridor to the south-eastern part of Europe was kept on the agenda primarily because of the further exacerbation of the conflict between Russia and Ukraine, the risks to the security of supply to Eastern and Central and South-eastern European countries, which resulted - among others - from the former, and the spread of the alternative natural gas supply and extraction projects outlined above.

An intergovernmental agreement was concluded about the project by Russia and Turkey in October 2016. The envisaged natural gas pipeline would

\footnotetext{
${ }^{14}$ The primary reason for this can be traced back to the energy policy debates between Moscow and Brussels. The about the previously outlined third energy package contributed to a large extent to the closure of the Southern Stream project. For more details, see Nógrádi \& Virág $(2015,39-43)$.
} 
have a land section and a 910-km long part running under the Black Sea, the latter financed by Gazprom. Pipe laying started in May 2017 and had been completed by the end of April 2018, when the first offshore section was laid in the proximity of Turkey's Black See coast.

One of the two land pipelines will only be allowed to supply natural gas to Turkey. This has a capacity of 15.75 billion cubic metres per annum, and will be in the 100 per cent ownership of the Turkish national mineral oil and natural gas company Botas. The other land pipeline will be allowed to transmit Russian natural gas to Europe through Turkey. Gazprom and Botas would have equal shares in the ownership of this $180-\mathrm{km}$ long section, which would also have a capacity of 15.75 billion cubic metres per annum.

\section{The TurkStream and the gatekeepers}

Right from the moment of suggesting the TurkStream Pipeline in 2014, Gazprom has given clear indications that among many other factors, this project should be understood in the context of the Russian-Ukrainian relationship.

Already in a December 2014 interview, given to the Russian public service television, Gazprom CEO Alexey Miller said that while Germany had a key intermediary role along the northern transport route (Nord Streams 1 and 2), ${ }^{15}$ Turkey would attend to the same duty along the southern line. During his talks with Maros Sefcovic, Vice-President of the European Commission and European Commissioner for the Energy, in January 2015, Miller confirmed his previous thought that Russia would redirect the natural gas supplied to its European partners through Ukraine to Turkey (Gazprom, 2015a). All this was a clear indication for Kiev that Gazprom would not give up the idea of establishing a gas pipeline bypassing Ukraine from the south after expiry of the transit agreement concluded by the Russians and the Ukrainians, and with this action gas supplies to Europe through the country may well be eliminated altogether.

Simultaneously with the completion of the TurkStream pipeline, in March 2018 Gazprom announced that they had started the cancellation of both longterm natural gas agreements concluded with Ukraine. ${ }^{16}$ If natural gas transit

\footnotetext{
${ }^{15}$ The Nord Stream, running along more than $1220 \mathrm{~km}$ and having a capacity of 55 billion cubic metres per annum, connects Russia directly with Germany under the Baltic Sea. The first part of the natural gas pipeline was handed over in November 2011, and the second in October 2012.Due to the already operative Nord Stream, Ukraine's role in Russian natural gas export has dramatically fallen from 70 to 40 per cent in the past few years.

${ }^{16}$ The Russian Gazprom and Naftogaz entered into two long-term natural gas agreements in 2009. One of them concerns the export of Russian natural gas to Ukraine, and the other is about transiting Russian natural gas through Ukraine to Europe. Both agreements were concluded for a definite period up to 31 December 2019. The document was approved when Yulia Tymoshenko was in office, who was then incarcerated on account of the agreement.
} 
through Ukraine is completely eliminated, Kiev would lose several billions of US dollars a year, due to missing transit charges. ${ }^{17}$ At the same time, with the participation of Russian and Ukrainian officials, negotiations started in Berlin in the spring of 2018 to settle the disputes that had evolved as a result of the fall in Russian natural gas transit in Ukraine. In early April Alexey Miller confirmed and, nuancing his previous statements, he declared that transit through Ukraine may fall to 10-15 cubic metres per annum when the supply of natural gas to Europe starts through the Nord Stream 2 and the TurkStream pipeline starts. All this was confirmed at the meeting of Vladimir Putin and Angela Merkel in Merseburg at the end of August 2018. It was declared that the alternative pipelines would "only" drastically reduce but not eliminate the role of the Ukrainian transit pipeline.

It is a fact that in relation to the TurkStream section running towards Europe, the potential new "gatekeeper" Turkey, used for route diversification, represented a serious uncertainty factor. The planned route of the natural gas pipeline to Turkey was set uring Alexey Miller's visit to Ankara in January 2015 The TurkStream would reach Europe along the route of the previously planned Southern Stream. According to this plan, $910 \mathrm{~km}$ the pipeline would run offshore, under the Black Sea, with the landing point at Kiyiköy and connecting to the Turkish natural gas supply network at the town Lüleburgaz, $74 \mathrm{~km}$ from the shore. Then it would run to the town Ipsala near the Greek border. According to the initial plans, four pipelines were planned to be built under the Black Sea, each enabling the transmission of 15.75 billion cubic metres of natural gas per annum. Thus in the aggregate, 63 billion cubic metres of natural gas would have been transmitted to Turkey, an amount identical with the previous plans for the Southern Stream. Of this, 47 billion cubic metres would be supplied to Europe, and 16 billion cubic metres directly to Turkey. At that time the first delivery was scheduled for December 2016 (Gazprom, 2015b).

Relations between Moscow and Ankara were rather turbulent and fluctuating between 2014 and 2018, right from the announcement of the parameters of the very first alternative pipeline plan and capacity. In the first phase, Turkey only wanted to implement the first section of the pipeline, which would have provided access to natural gas for their own consumption. In addition, the Turkish authorities withheld the authorizations required for the pipeline construction, and Ankara liked to speak of the TANAP pipeline, a competitor to the Russian one. Right at the beginning of the procedure, all this shed light to the fact that the management of the TurkStream was more important for the Russian than for the Turkish party, or at least the latter has a stronger bargaining power than previously expected in Moscow. For a short

${ }^{17}$ In 2017 Ukraine transited 93.5 billion cubic metres of Russian natural gas. Kiev earned USD 3.5 billion on this business, representing 3 per cent of the country's annual GDP. 
while it seemed that the pipeline project may well be withdrawn from the agenda. ${ }^{18}$ Finally, after the normalization of Russian and Turkish relations, preparation of the TurkStream was started.

It is a fact that the planned volume of natural gas that can be transmitted through the Turkish Stream has fallen from the previously expected 63 billion cubic metres to 32 cubic metres per annum. Meanwhile, in the relationship between Ukraine and Russia, this has not reduced Moscow's blackmailing potential against Kiev. This is because despite halving the planned capacity of the TurkStream, the capacity of the NordStream, also avoiding Ukraine, may double if the Nord Stream 2 concept is implemented, as discussed below.

\section{The TurkStream and regaining the confidence of European consumers}

Strategically, Moscow handles the western and eastern Member States of the EU separately. The Member States that accessed the European Union in 2004 are transit countries and well-paying markets at the same time. For this reason, the Russian leadership endeavoured to either avoid the region by an alternative natural gas pipeline (see the Nord Streams 1 and 2), or to make them interested in Russian-inspired projects even by dividing them if they participated in projects adversely affecting the Russian objectives. This was actually the essence of the Southern Stream, and later on the concept of the TurkStream.

As explained above, Gazprom would not give up the idea of establishing a natural gas pipeline bypassing Ukraine from the south upon, and simultaneously gives indications from time to time that on expiry of the transit agreement between the Russians and the Ukrainians, the complete termination of natural gas supplies to Europe through the country is not excluded. All this represents a major challenge for the countries of Southeast, Central and Eastern Europe.

According to the plans, the pipeline called TurkStream is not allowed to reach Europe, and can only run up to the border between Greece and Turkey, the partner countries purchasing natural gas from Russia would need an appropriate gas pipeline network within a short time frame to reach the gas distributor planned in Western Turkey. Without the Ukrainian transit, Slovakia

\footnotetext{
${ }^{18}$ Many consider the shooting of the Russian fighter-bomber serving in Syria as the main reason for taking the TurkStream off the agenda for the time being, as Russia suspended the preparatory works for the construction of the natural gas pipeline TurkStream. The truth may rather be that with reference to the political tension, Russia waved the project about which talks had been suspended well before the incident, approximately at the time when the idea of the Russian-inspired Nord Stream 2 pipeline project emerged, as discussed below.
} 
may lose its previous key role and transit revenues. ${ }^{19}$ Undoubtedly, Bulgaria may lose the most, as 90 per cent of its natural gas is imported from Russia. ${ }^{20}$

The gap caused by the failure of the Southern Stream required numerous alternative concepts in the Eastern and Central European and in the Southeastern European regions regarding connection to the TurkStream. Thus a competition that may not be considered as exceptional started in energy for the connection of Europe to the natural gas supply transmitted through the TurkStream, ${ }^{21}$ and this reduced the chances of implementing other alternative concepts. Gazprom also came up with an alternative route running through Bulgaria, Serbia and Hungary to contest other competing network developments in the region. This is enabled by the project companies in charge of the implementation of the European section of the previous Southern Stream in the above-specified countries, and negotiations have started with Serbia about the Serbian Stream and with Bulgaria about the Bulgarian Stream.

The TurkStream may mitigate the risks to the security of supply in numerous Central and Eastern European Countries, also in respect of another Russian-inspired project, the Nord Stream 2. While consultations on the implementation of a southern natural gas corridor (whether the Nabucco, the Blue or the Southern Stream or any other project) have been ongoing for more than a decade with the involvement of a dozen countries in the eastern and south-eastern periphery of the European Union, despite the relations between the West and Russia, simply coined as the "new cold war", Gazprom intends to construct two new pipelines of an aggregate capacity of 55 billion cubic metres parallel to the already existing Nord Stream, under the name "Nord Stream 2", in the framework of the German-Russian bargain.

The Russian company expects to hire considerable European companies for the implementation of the project. Gazprom's partners include the DutchBritish Shell, the German Uniper and Wintershall, the British-Danish Royal Dutch Shell, the Austrian OMV and the French Engie. Each of the five European companies invest EUR 950 million in the 9.5 billion project. The

${ }^{19}$ A significant part of the natural gas is transmitted from Russia by transit through Ukraine and Slovakia to Western Europe. The network manager Eustream makes a profit of several hundred million euros in Slovakia annually. The company is in the 51 per cent ownership of the Slovakian state, and the central budget earns about EUR 160 million annually (Lajos P., 2015).

${ }^{20}$ Due to its geographical situation, Bulgaria had a significant role in the alternative natural gas project. A glimpse is given into the bargain between Russia and Bulgaria in relation to the Southern Stream pipeline in a paper by Jim Yardley and Jo Becker, published in the New York Times in late 2014 (Yardley \& Becker, 2014).

${ }^{21}$ Outstanding alternative plans include the Tesla and the Eastring projects. For more details, see (Virág, 2016, p. 97-99). 
single shareholder of the Nord Stream 2 remains the Russian Gazprom. ${ }^{22}$ From a Russian perspective, the advantage of the network running along more than $1220 \mathrm{~km}$ with an annual capacity of 55 billion cubic metres against its southern counterparts is that it connects Russia directly with Germany on a route under the Baltic Sea. Thus there would be no gatekeeper between the Russian Viborg and the German Greifswald to prevent the operation of the network transmitting additional 55 billion cubic metres per annum. Moreover, the route is $2000 \mathrm{~km}$ less than the one currently supplying Russian natural gas to some of the EU Member States through Ukraine.

Perhaps not coincidentally, the start date of deliveries was expected in late 2019 , just at the time when Russia held out the prospects of stopping supply to Europe through Ukraine. In the aggregate, the Nord Stream 2 project thus increases the risk that after the expiry of the Ukrainian transit agreement, the pivotal European transit route in Ukraine, currently having an approximate annual capacity of 150 billion cubic metres, ceases to exist. The risks have a serious impact on the Eastern and Central European countries directly connected to the Ukrainian transit network and may consequently lose their current transit positions.23 In addition to the losses of transit revenues, their current bargaining power vis-a-vis the Russian supplier regarding the trade agreements for the supply of natural gas may decrease. Thus, there is a reason seven EU Member States, including Hungary, Poland, Romania, Slovakia and the three Baltic states called the attention of the European Commission in December 2015, after shareholders' agreement about the Nord Stream 2, to the adverse impacts of the Russian-German project aimed at the expansion of the Nord Stream on the security of energy supply.According to the authors of the letter, "the maintenance of the transport route through Ukraine is in the strategic interest of the EU" (Bruxinfo, 2016). In their opinion, if the Nord Stream 2 pipeline is built and natural gas transit through Ukraine is terminated after 2019, with the sole exception of the Jamal pipeline, all the Russian natural gas export routes to the EU would enter the Union in Germany. This would undermine the security of supply to Europe in comparison to the current status quo.

However, it is a fact that originally there were ten Member States against Nord Stream 2. With the exception of Slovenia and Croatia, all the Eastern European Member States of the EU seemed to give voice to concerns about

${ }^{22}$ According the previous plans, European investors would have purchased 50 per cent of Gazprom's shares; each company would have obtained 10 per cent interest. This plan was sent to the German and Polish competition authorities for judgment. However, the competent Polish authority rejected the plan of the joint venture established by the acquisition of the ownership share, and so the affected companies abandoned the original concept.

${ }^{23}$ In terms of diversification, in addition to the Ukrainian network, the significance of the Slovakian, Hungarian and Romanian transit networks may also decrease significantly in an east-west direction. 
this topic. Finally, the Czech Republic, as a would-be eastern distributor of the natural gas supplied through the Nord Stream 2, and Bulgaria and Greece, affected in the TurkStream, refused to sign the letter written in protest.

With consideration to all these, interestingly, the Eastern European grievances caused by the Nord Stream 2 pipeline may be relieved by keeping the TurkStream, another Russian-inspired project, on the agenda, despite the fact that at the time the study was made, only the first branch, supplying Turkish consumers, was expected to be built. The construction of the second branch is only envisaged after Gazprom has been given firm guarantees from the European Commission.24

\section{The TurkStream and the blocking of alternative sources}

Similarly to the previous Southern Stream project, the TurkStream can be considered as a kind of a blocking project, which renders it difficult to implement other projects suitable for the transmission of natural gas from alternative sources to Eastern and Central as well as South-eastern Europe. Such pipelines under construction include the above described TransAnatolian gas pipeline (TANAP), which may enable the transmission of Azeri natural gas through Turkey to Europe.

Although currently Gazprom has no reasonable chance to actually block the project, through TAP it may secure an exclusive opportunity for itself for Southern European flows, in other words, it may block connection to the previous Nabucco route by keeping the TurkStream on the agenda. Thus Gazprom's current positions may be weakened in the Southern European region by 10 billion cubic metres of natural gas molecules transmitted from Azerbaijan, but the company may retain and perhaps improve its positions in South-eastern and Eastern and Central Europe.

Another key issue for Russia is to promise and provide piped natural gas extracted on its own with conditions that are more favourable than the existing ones applied in Eastern Europe and those applied to the planned LNG terminals. In this respect, the LNG terminal already operative in Poland, and the one waiting for implementation in Croatia are of outstanding significance, as through these terminals, Eastern-European countries may purchase natural gas in bulk from the competitor United States in the future.

It is no accident that in September 2017, the Russian natural gas industrial company Gazprom signed a long-term gas supply contract with the largest Croatian natural gas importer. The contracted amount will be sufficient to

\footnotetext{
24 "Now for the Western Balkans might be interested in another new project — Turkish Stream. And how we are ready to collaborate on this project, we have repeatedly said, if you're interested EU countries to gas via this pipeline went to the territory of the EU, you need an absolute guarantee from the European Commission, in General, from the European Union" Seregei Lavrov said at a press conference in Moscow (Russia News, 2018).
} 
cover nearly the total volume imported by Croatia, thus rendering the LNG terminal near the Island of Krk unnecessary. The TurkStream is one of the alternatives for the secure transmission of the contracted volume. For Russia it is an advantage in the region that the currently the transmission of natural gas through pipes is considerably cheaper then the LNG version.

In addition to the Russian alternative projects, among other factors, the high investment costs also contribute to the delay in implementation of the Croatian terminal. Originally, construction should have started in mid-2016 in order to have it completed by 2019 (when the long-term Russian-Ukrainian natural gas agreement expires). Even if implementation starts in 2018, a twoyear delay should still be expected.

\section{Conclusion}

Russia's peculiar energy security considerations are due primarily to the unique geographical conditions and to its European relations in piped natural gas transmission. For this reason the Russian strategy focuses on the security of demand in relation to Europe.

In the perspective of Russian energy security, the concept of the TurkStream was inspired and affected by a large number of events. The escalation of the conflict between Moscow and Kiev poses serious risks to the future transit of Russian natural gas to the West. Deteriorating relations with the USA and the EU have led to numerous decisions and sanctions harmful for Russia. To make matters worse, a boom in the unconventional American natural gas extraction and LNG export, and the loss of confidence in the European markets may change the European natural gas status quo over time. In the reviewed period, competition has already evolved between the transmission of LNG and the traditional, primarily Russian, piped natural gas, and between natural gas from Russian and other (e.g. Romanian and Azeri) sources. It is clear, that in this situation, the EU's role as a buyer is appreciated $^{25}$.

In view of these challenges, the TurkStream is a kind of response to numerous alternative natural gas projects, whether planned or under implementation, in or aimed at Europe. The TurkStream can also be considered as a Russian-inspired plan that promotes a triple objective and facilitates the security of demand (see Table 1), in the case of natural gas supply to the West, primarily measured by the maintenance of or increase in the existing Russian power positions rather than implementation alone.

\footnotetext{
${ }^{25}$ This development is global and does not only relate to the USA-Russian relations. Between 2017 and 2023, global trade in LNG is expected to increase by more than 100 billion cubic metres, from 391 billion to 505 billion cubic metres.
} 


\begin{tabular}{|c|c|l|c|l|c|}
\hline & Russian challenges & Russian strategy & & $\begin{array}{c}\text { The TurkStream in the } \\
\text { service of the Russian } \\
\text { natural gas strategy }\end{array}$ \\
\hline 2 & $\begin{array}{c}\text { The Russian- } \\
\text { Ukrainian conflict }\end{array}$ & $\rightarrow$ & $\begin{array}{c}\text { Pacification / by- } \\
\text { passing the } \\
\text { Ukrainian transit }\end{array}$ & $\rightarrow$ & $\begin{array}{c}\text { The TS as an alternative } \\
\text { for by-passing the } \\
\text { Ukrainian transit from the } \\
\text { south }\end{array}$ \\
\hline 3 & $\begin{array}{c}\text { Anti-Russia } \\
\text { sanctions/decisions } \\
\text { Alternative Eastern } \\
\text { European natural gas } \\
\text { projects }\end{array}$ & $\rightarrow$ & $\begin{array}{c}\text { Regaining the } \\
\text { confidence of } \\
\text { European } \\
\text { consumers }\end{array}$ & $\rightarrow$ & $\begin{array}{c}\text { The TS as a promise to the } \\
\text { eastern part of the EU for } \\
\text { the maintenance of the } \\
\text { status quo }\end{array}$ \\
\hline
\end{tabular}

Table 1 The TurkStream Pipeline and the security of demand for Russian natural gas

One of the focal points in the Russian strategy is to blackmail Kiev with the concept of the TurkStream viewed as an alternative natural gas corridor avoiding Ukraine. Keeping the project on the agenda may improve Russia's bargaining power in the event of a future Russian-Ukrainian natural gas agreement, while the eventual connection of the planned network to Europe would appreciate Turkey as a new and alternative gatekeeper, involving additional future risks for Russia in addition to / instead of the old partner, Ukraine.

As in addition to the USA, the EU also applies sanctions against Russia on account of the situation that has evolved in Ukraine, in addition to the pacification or avoidance of Ukraine, acting as a gatekeeper, the expansion of Western allies in the natural gas sector is important for Moscow, and this end may be served by the Nord Stream 2 project primarily in relation to Germany. Meanwhile, the mentioned project would further improve the infrastructure of Western European countries, which already have a highly developed natural gas pipeline network, as against the more poorly supplied Eastern European countries, which may be compensated for the closing up of or reduction in the Ukrainian transit route by the promise of the TurkStream. Naturally, all this presumes that the network will once reach the old continent beyond Turkey.

The TurkStream can also be considered as a kind of a blocking project, which renders it difficult to implement other projects suitable for the transmission of natural gas from alternative sources to Eastern and Central as well as South-eastern Europe. These include Eastern Europe's connection to the Southern European network, intended to transmit Azeri natural gas to Europe (TANAP-TAP) or to the BRUA Pipeline planned to transmit Romanian gas from the Black Sea.

For the time being it seems that despite the promise made by the TurkStream, the "additional capacities" facilitating the avoidance of Ukraine 
are more likely to be built along the German-Russian route, i.e. in the north, than along the Turkish-Russian route in the south, however, there are several indications that the Nord Stream 2 alone will be insufficient to replace the Ukrainian natural gas transit after the Russian-Ukrainian natural gas agreement expires at the end of 2019.

The causes include the expected increase in European natural gas demand, and the fact that the European pipe network intended to distribute the total natural gas capacity received through the Nord Stream 1 and 2 will not have been completed by 2019 expiry of the long-term Russian-Ukrainian natural gas agreement. ${ }^{26}$ In sum, the transit of natural gas through Ukraine with unknown conditions and the concept of the TurkStream jeopardizing the former may both remain on the table.

\section{References:}

1. BP (2018). Statistical Review of World Energy, June 2018.

2. Blaskovics, B. (2016). The impact of project manager on project success: The case of ICT sector Society and Economy, 38(2), 261-281.

3. Bruxinfó (2016). Rezeg a léc az Északi Áramlat alatt. Retrieved from: http://bruxinfo.hu/cikk/20160208-rezeg-a-lec-az-eszaki-aramlatalatt.html, Accessed: 25.02.2016.

4. Buzan, B., Waever, O. \& de Wilde, J. (1998). Security: A New Framework for Analysis. Bouder: Lynne Rienner Publishers.

5. CAATSA (2017). Countering America's Adversaries Through Sanctions Act. Retrieved from: https://www.treasury.gov/resourcecenter/sanctions/Programs/Pages/caatsa.aspx, Accessed: 14.08.2018.

6. Cherp, A., Adenikinju, A., Goldthau, A., Hernandez, F., Hughes, L., Jansen, J., Jewell, J., Olshanskaya, M., Soares de Oliveira, R., Sovacool, B. \& Vakulenko, S. (2012). Energy and security. In Johansson, T. B., Nakicenovic, N. \& Patwardan, A. (Eds.), Global Energy Assessment: Toward a Subtainable Future. (p. 325-383). Cambridge, NY: Cambridge University Press.

7. Deutsch, N. (2013). Decentralizált települési energiarendszerek potenciális közösségi hatásai. In: Somogyvári, M. \& Kiss, T. (Eds.). Via Futuri 2012: Irányváltás? 160 p., Pécs: Pécsi Tudományegyetem Közgazdaságtudományi Kar (PTE KTK), pp. 121-136.

8. European Commission (2017). EU invests $€ 444$ million in key energy infrastructure. Brussels, 1702 2017. Retrieved from: http://europa.eu/rapid/press-release IP-17-280_en.htm, 12.08.2018.

\footnotetext{
${ }^{26}$ In this context, remember the bottlenecks in land transport capacity, primarily delays in the implementation of Eugal, the pipe section in Germany for the transmission of gas (Stier, 2018).
} 
9. Gazprom (2015a). Alexey Miller and Maros Sefcovic address issues of reliable gas supply to European consumers. 2015. 01. 14. Retrieved from:

http://www.gazprom.com/press/news/2015/january/article212264/, Accessed: 02.02.2015.

10. Gazprom (2015b). New Russia - Turkey gas pipeline route approved at meeting in Ankara. Retrieved from: http://www.gazprom.com/press/news/2015/january/article213570, Accessed: 23.08.2018.

11. Lajos P. J. (2015). Moszkva a gázzal játszik. Retrieved from: http://ujszo.com/online/gazdasag/2015/04/14/moszkva-a-gazzaljatszik, Accessed: 30.08.2018.

12. List of actions selected for receiving financial assistance under the second CEF Energy 2016 call for proposals (2017). Retrieved from: https://ec.europa.eu/energy/sites/ener/files/documents/list_of_all_proj ects_receiving_eu_support_under_the_current_call.pdf 2 Accessed: 2018. 08. 12.

13. Marshall, T. (2016). Prisoners of Geography. Ten Maps That Tell You Evverything You Need To Know About Global Politics. London: Elliott and Thompson Limited.

14. Nógrádi, Gy. \& Virág, A. (2015). A Déli Áramlat projekt lezárása az orosz stratégia nézőpontjából. Külügyi Szemle, 14(1), 30-50.

15. Russia News (2018). Lavrov: for the supply of gas to the EU via the «Turkish stream» is needed $100 \%$ guarantee. Retrieved from: https://chelorg.com/2018/06/13/lavrov-for-the-supply-of-gas-to-theeu-via-the-turkish-stream-is-needed-100-guarantee/, Accessed: 2018. 08. 13.

16. Stier, G. (2018). Lassú munka hátráltatja az Északi Áramlat 2-t. mno.hu, 31.03.2018, Retrieved from: https://mno.hu/moszkvater/lassumunka-hatraltatja-az-eszaki-aramlat2-t-2457079, Accessed: 24.08.2018.

17. Tarar, A., Andrianova, A., Meyer, H. \& Dodge, S. (2018). Putin Is Sure of Victory, But Little Else, Bloomberg, Retrieved from: https://www.bloomberg.com/graphics/2018-putin-performance/, Accessed: 11.08.2018.

18. Virág, A. (2014). Elgázolt szuverenitás. Budapest: Geopen Kiadó.

19. Virág, A. (2016). Áramlatok örvényében, Gázdiverzifikációs játszmák Kelet-Közép-Európában. Köz-Gazdaság, 13(2), 94-106.

20. Weiner, Cs. (2017). Energiaellátás-biztonság és gázdiverzifikáció Magyarországon, Elmélet és gyakorlat. Centre for Economic and Regional Studies of the Hungarian Academy of Sciences - Institute of 
World Economics, Mühelytanulmányok 121. Retrieved from: http://real.mtak.hu/72294/1/MT_121_Weiner.pdf, Accessed: 04.08.2018.

21. Wicks, M. (2009). Energy security: A national challenge in a changing world.

http://130.88.20.21/uknuclear/pdfs/Energy_Security_Wicks_Review_ August_2009.pdf_Accessed: 04.08.2018.

22. Yardley, J. \& Becker, J. (2014). Putin's Way, How Putin Forged a Pipeline Deal That Derailed. The New York Times, 30.12.2014., Retrieved from: https://www.nytimes.com/2014/12/31/world/europe/how-putinforged-a-pipeline-deal-that-derailed-.html, Accessed: 20.08.2018. 